\title{
Technological quality of common bean grains obtained in different growing seasons
}

\author{
Eliana Francischinelli Perina $\left({ }^{1 *}\right)$; Cássia Regina Limonta Carvalho $\left({ }^{2}\right)$; Alisson Fernando Chiorato $\left({ }^{3}\right)$; \\ Rodrigo Lorencetti Tunes Lopes (3,4); João Guilherme Ribeiro Gonçalves ( ${ }^{3}$ ); Sérgio Augusto Morais \\ Carbonell (3)
}

(1) Instituto Agronômico de Campinas (IAC), Av. Barão de Itapura, 1481, 13020-902 Campinas (SP), Brasil.

(2) IAC, Centro de Pesquisa e Desenvolvimento de Recursos Genéticos Vegetais, 13020-902 Campinas (SP), Brasil.

(3) IAC, Centro de Análise e Pesquisa Tecnológica do Agronegócio de Grãos e Fibras, 13020-902 Campinas (SP), Brasil.

(4) IAC, Programa de Pós-graduação em Genética e Melhoramento Vegetal, 13020-902 Campinas (SP), Brasil.

${ }^{*}$ ) Corresponding author: efperina@yahoo.com.br

Received: Sept. 29, 2013; Accepted: Jan. 17, 2014

\begin{abstract}
The traits that provide technological quality to common bean grains exhibit genetic and environmental variation and variation in the genotype $x$ environment interaction. In this context, the aim of this study was to assess the effect of different periods of the growing season on the technological quality of common bean grains. The experiment was conducted with 25 bean genotypes (carioca [beige with brown stripes] and black commercial group) that are part of the Value for Cultivation and Use (Valor de Cultivo e Uso - VCU) trials in three growing seasons, namely, the 2009/2010 rainy season, the 2010/2011 dry season and the 2010/2011 winter season, in a randomized block experimental design with three replications in which the following items were assessed: cooking time (CT), water absorption capacity before cooking (Peanc) and after cooking (Peapc), percentage of whole grains (PWG), total soluble solids in the broth (TSSb), volume expansion before cooking (EXPVbc) and after cooking (EXPVac), and dry grain density (DD), grain density after maceration (SD) and grain density after cooking (CD). Assessments showed that the different growing seasons for obtaining grains for the purpose of analysis of technological quality have an effect on the results and on differentiation among genotypes, indicating genotype $x$ environment interaction. They also showed that the genotypes C2-1-6-1, C4-8-1-1, LP04-03, IAC-Imperador, P5-4-4-1 and Pr1 1-6-4-1-2 had the best results in relation to cooking time in the mean values of the three growing seasons. The use of early selection based on phenotypic correlations that exist among the technological features is not expressive, due to the variation of magnitude among the different growing seasons.
\end{abstract}

Key words: Phaseolus vulgaris L, common bean, cooking time, genotype by environment interaction.

\section{Qualidade tecnológica dos grãos de feijoeiro obtidos em diferentes épocas de cultivo}

\section{Resumo}

Os caracteres que conferem qualidade tecnológica aos grãos de feijão apresentam variação genética, ambiental e da interação genótipos x ambientes. Nesse contexto, o objetivo do trabalho foi avaliar a influência de épocas de cultivo na qualidade tecnológica dos grãos de feijoeiro. $O$ experimento foi conduzido com 25 genótipos de feijoeiro (grupo comercial carioca e preto) pertencentes aos ensaios de VCU (Valor de Cultivo e Uso) nas três épocas de cultivo, correspondendo à época das águas 2009/2010, da seca 2010/2011 e do inverno 2010/2011, sob delineamento experimental em blocos ao acaso com três repetições, onde avaliaramse: tempo de cozimento (TC), capacidade de absorção de água antes (Peanc) e após (Peapc) o cozimento, porcentagem de grãos inteiros (PGI), sólidos solúveis totais no caldo (SSTc), expansão volumétrica antes (EXPVac) e após (EXPVpc) o cozimento e densidade dos grãos secos (DS), macerados (DU) e cozidos (DC). As avaliações revelaram que as épocas de cultivo dos grãos para análise de qualidade tecnológica influenciam nos resultados e na diferenciação entre os genótipos, indicando interação genótipo por ambiente. Também reportaram que os genótipos C2-1-6-1, C4-8-1-1, LP04-03, IAC-Imperador, P5-4-4-1 e Pr1 16-4-1-2 sobressaíram-se em relação ao tempo de cozimento na média das três épocas. O uso de seleção precoce com base em correlações fenotípicas existentes entre as características tecnológicas não é expressivo devido à variação de magnitude entre as diferentes épocas de cultivo.

Palavras-chave: Phaseolus vulgaris L., feijão, tempo de cozimento, interação genótipo por ambiente. 


\section{INTRODUCTION}

Common bean (Phaseolus vulgaris $\mathrm{L}$ ), or edible beans or dry beans, present in the Brazilian diet, is an excellent food from a nutritional standpoint since it provides essential nutrients, such as proteins, iron, calcium, vitamins (especially B complex), carbohydrates, fiber and lysine, which is an essential amino acid (Mesquita et al., 2007).

In Brazil, in addition to being a crop of great socioeconomic importance, common bean is an important food, especially since it is a lower cost source of protein compared to products of animal origin.

Common bean genetic breeding programs have provided producers with cultivars with high grain yield, along with tolerance to pests and diseases, as well as production of grains of a size, shape, color and sheen acceptable in the market. In addition, the beans should have desirable cooking features, such as reduced cooking time, good palatability, soft texture of the seed coat and the ability to produce a clear, dense broth after cooking (Mesquita et al., 2007).

As of 1999, according to Portaria 294 (Ministerial Directive 294) of $14 / 10 / 98$, testing of technological quality came to be required at the time of registration of a new bean cultivar with the National Cultivar Registry (Registro Nacional de Cultivares - RNC) of the Ministry of Agriculture, Livestock and Food (Ministério da Agricultura, Pecuária e Abastecimento - MAPA) for the cultivar to become a commercial seed product in Brazil (BRASIL, 2001). Currently, the main parameters related to grain quality and required by the MAPA directive are determination of cooking time and the protein content of the genotypes that are included in the experiments called "Value of Cultivation and Use (VCU).

Determination of the technological quality of the bean grains involves testing of water absorption before and after cooking, cooking time, percentage of peel and soluble solids in the broth, and color of the seed coat and broth. Nutritional quality testing includes assessments of crude protein, dietary fiber, mineral and vitamin contents (Bassinello et al., 2003).

In addition to the existence of genetic variability for cooking time, local growing conditions in effect during plant and grain development have a direct effect on the results and on differentiation among genotypes. Various authors have reported the existence of the genotype and environment interaction for this characteristic, with differences being observed in behavior of lines and cultivars in different locations, crop years and planting times (Carbonell et al., 2003; Ribeiro et al., 2007; Rodrigues et al., 2004; 2005b). Bordin et al. (2010), evaluating 22 genotypes of common bean, observed a variation from 19.5 to 47.5 minutes (average of 33.3 minutes) in the 2006/2007 crop season, and from 17.5 to 28 minutes (average of 23.4 minutes) in the $2007 / 2008$ crop season for cooking time, considering 8 hours of soaking time prior to cooking.
Therefore, the aim of this study was to assess the effect of different periods of the growing season on the technological quality of common bean grains.

\section{MATERIAL AND METHODS}

The common bean genotypes that were part of regional experiments in the Value for Cultivation and Use (VCU) trails in the state of São Paulo in the 2009/2010/2011 twoyear period were evaluated in regard to the technological quality of their grains. In this study, a total of 25 genotypes belonging to the main common bean breeding programs of the country were evaluated, namely, ten lines from IAC (carioca [beige with brown stripes] seed coat: C2-1-6-1, C2-1-6-1-1, C2-3-1-1-2, C4-5-4-1-2, C4-8-1-1, P5-4-31, P5-4-4-1; black seed coat: $\operatorname{Pr} 11-6-4-1-2, \operatorname{Pr} 11-3-5-1$ and Pr14-2-3-2); four lines from EMBRAPA (carioca seed coat: BRS-Estilo and BRS-Cometa; black seed coat: BRS-Esplendor and CNFC 10104); three lines from IAPAR (carioca seed coat: Eldorado, LP-04-03 and LP-05-77); two lines from EPAGRI (carioca seed coat: CHC97-29; black seed coat: CHP98-59) and two lines from UFLA (carioca seed coat: MAII-22 and RP-2). The standard cultivars used for the carioca commercial group were IAC Alvorada and Pérola, and for the black commercial group IAC Una and IAC Diplomata. The trails were set up in accordance with the guidelines of the National Cultivar Protection Service of the Ministry of Agriculture (SNPC/MAPA).

The environments and the respective crop seasons used for conducting the field experiments were Capão Bonito and Mococa in the 2009 rainy crop season; Avaré, Mococa and Tatuí in the 2010 dry crop season; Andradina, Espírito Santo do Pinhal and Votuporanga in the 2010 winter crop season; Avaré, Capão Bonito and Mococa in the 2010 rainy crop season; Avaré, Capão Bonito and Mococa in the 2011 dry crop season; and Colina, Ribeirão Preto and Votuporanga in the 2011 winter crop season.

The technological quality of the grains was assessed in a period of up to 60 days after harvest of the genotypes. Grain samples were first homogenized and classified in sieves with oblong holes of $13 / 64 \times 3 / 4 "(5.16 \times 19.05 \mathrm{~mm})$ and pre-analyzed for removal of grains visibly damaged from insects or from mechanical processes. After selection, the grains were stored in domestic use refrigerators with a stable temperature of $10{ }^{\circ} \mathrm{C}$.

Water absorption capacity before cooking (Peanc), water absorption capacity after cooking (Peapc) and the percentage of whole grains (PWG) were determined in accordance with the modified methods described in the scientific article of Garcia-Vela and Stanley (1989) and Plhak et al. (1989). According to the modified method proposed by these authors, a $30 \mathrm{~g}$ sample of bean grains was placed in a $250 \mathrm{~mL}$ beaker with $100 \mathrm{~mL}$ of distilled water 
for 16 hours at ambient temperature. After the soaking period, the water was drained, the grains were weighed and the water absorption capacity before cooking (Peanc) was calculated by the formula: $[(\mathrm{sw}-\mathrm{dw}) / \mathrm{dw}] \times 100$, in which $\mathrm{dw}=$ beginning weight of dry grains; $\mathrm{sw}=$ grain weight after maceration. The drained grains were once more placed in the beaker, with $100 \mathrm{~mL}$ of distilled water, and were then heated for an hour by an electric hot plate, beginning time count when the water began to boil. The broth was then drained and water absorption capacity after cooking (Peapc) was calculated by the formula: $[(\mathrm{cw}-\mathrm{dw}) / \mathrm{dw}] \times 100$, in which $\mathrm{dw}=$ beginning weight of dry grains; $\mathrm{cw}=$ weight of grains after cooking. After cooking, the grains were counted and separated in two groups: whole and partitioned grains. Then, the percentage of whole grains after cooking was calculated by the formula PWG $(\%)=(\mathrm{ng} / \mathrm{nwg}) \mathrm{x} 100$, in which ng = total number of grains and nwg = number of whole grains after cooking.
Mean cooking time (CT) was determined using $30 \mathrm{~g}$ of uniform whole seeds soaked in distilled water for 16 hours at ambient temperature. After this period, twenty-five grains were individually placed in the orifices at the base of the Mattson cooker and the apparatus was placed in a beaker containing $1000 \mathrm{~mL}$ of boiling distilled water. Mean cooking time was registered in minutes up to the fall of the 13th plunger, which consists of $50 \%$ of the grains perforated by the rods of the apparatus (Proctor and Watts, 1987).

For determinations of the characteristics related to volumetric expansion and density of the grains, $10 \mathrm{~g}$ of raw grains were weighed, which were soaked in distilled water for 16 hours at environmental temperature. After this period, the water was drained and the grains were weighed. The grains were then placed in glass jars with screw tops and $100 \mathrm{~mL}$ of boiling water was added and the grains were cooked in a bain marie for 1 hour. The volume of the raw, macerated and cooked grains was determined using the water displacement principle - bean grains were added

Table 1. Values of water absoption capacity before cooking (Peanc) and after cooking (Peapc), cooking time (CT), percentage of whole grains after cooking (PWG), volumetric expansion before cooking (EXPVbc) and after cooking (EXPVac), dry/raw grain density (DD), grain density after soaking (SD) and grain density after cooking (CD) and total soluble solids in the broth (TSSb) of the grains of cultivars/ lines of common bean, grown in the winter season in the 2010/2011 crop years in the state of São Paulo

\begin{tabular}{|c|c|c|c|c|c|c|c|c|c|c|}
\hline $\begin{array}{c}\text { Cultivars and } \\
\text { Lines }\end{array}$ & $\begin{array}{l}\text { Peanc } \\
(\%)\end{array}$ & $\begin{array}{c}\text { Peapc } \\
(\%)\end{array}$ & $\begin{array}{c}\mathrm{CT} \\
\text { (min.) }\end{array}$ & $\begin{array}{l}\text { PWG } \\
\text { (\%) }\end{array}$ & $\begin{array}{c}\text { EXPVbc } \\
(\%)\end{array}$ & $\begin{array}{c}\text { EXPVac } \\
(\%)\end{array}$ & $\begin{array}{c}\text { DD } \\
\text { (g.mL) }\end{array}$ & $\begin{array}{c}\text { SD } \\
\text { (g.mL) }\end{array}$ & $\begin{array}{c}\mathrm{CD} \\
\text { (g.mL) }\end{array}$ & $\begin{array}{c}\text { TSSb } \\
(\%)\end{array}$ \\
\hline C2-1-6-1 & 113.75 & 147.34 & 33.39 & 16.6 & 58.59 & 65.93 & 1.30 & $1.15^{*}$ & 1.08 & 12.20 \\
\hline$C 2-1-6-1-1$ & 108.24 & 155.14 & 31.17 & $80.36^{*}$ & $72.73^{*}$ & $76.92^{*}$ & $1.96^{*}$ & $1.15^{*}$ & 1.09 & 13.81 \\
\hline$C 2-3-1-1-2$ & 108.48 & 146.68 & 34.57 & 28.46 & 66.67 & 69.23 & 1.47 & 1.02 & 1.08 & 13.02 \\
\hline C4-5-4-1-2 & 104.69 & 148.44 & 40.35 & $57.53^{*}$ & 66.67 & 66.67 & 1.46 & 1.02 & 1.16 & 12.83 \\
\hline C4-8-1-1 & 108.44 & 146.65 & 32.58 & $67.95^{*}$ & 68.69 & 70.94 & $1.63^{*}$ & 1.06 & 1.11 & 11.18 \\
\hline CHC 97-29 & 101.31 & 155.18 & 32.25 & 38.97 & $74.24^{*}$ & $78.02^{*}$ & $2.00^{*}$ & 1.07 & 1.07 & 12.91 \\
\hline CHP 98-59 & 100.9 & 147.69 & 34.34 & 18.57 & 66.67 & 60.00 & 1.50 & 1.05 & 1.36 & 12.06 \\
\hline CNFC 10104 & 98.76 & 141.7 & 31.51 & $52.96^{*}$ & 54.55 & 50.00 & 1.21 & $1.21^{*}$ & $1.46^{*}$ & 11.80 \\
\hline BRS-Cometa & 101.78 & 147.62 & 35.19 & $65.74^{*}$ & 60.00 & 60.00 & 1.51 & $1.25^{*}$ & 1.36 & 11.58 \\
\hline Eldorado & 104.06 & 134.19 & 37.09 & 35.82 & 60.40 & 56.67 & 1.40 & $1.17^{*}$ & $1.39^{*}$ & 11.39 \\
\hline BRS-Esplendor & 93.86 & 148.33 & 36.05 & $76.25^{*}$ & $81.82^{*}$ & $84.62^{*}$ & $2.05^{*}$ & 1.08 & 1.11 & 13.29 \\
\hline BRS-Estilo & 105.93 & 150.12 & 36.6 & 48.35 & 53.03 & 55.84 & 1.20 & $1.16^{*}$ & $1.26^{*}$ & 13.28 \\
\hline LP-04-03 & 108.41 & 149.6 & 31.27 & 43.94 & 54.55 & 50.00 & 1.20 & 1.12 & $1.47^{*}$ & $13.96^{*}$ \\
\hline LP-05-77 & 104.98 & 147.76 & 36.21 & 51.56 & 58.33 & 64.29 & 1.21 & 1.04 & 1.04 & $13.89^{*}$ \\
\hline MAll-22 & 111.72 & 135.59 & 39.02 & 51.56 & 54.55 & 61.54 & 1.20 & 1.13 & 1.12 & 11.59 \\
\hline IAC Imperador & 102.96 & 132.36 & 34.01 & $64.35^{*}$ & 55.81 & 58.61 & 1.20 & 1.10 & $1.21^{*}$ & 11.56 \\
\hline P5-4-4-1 & 105.32 & 142.23 & 28.23 & $64.87^{*}$ & 63.64 & 66.67 & 1.51 & 1.11 & $1.20^{*}$ & 13.02 \\
\hline Pr1 1-3-5-1 & 105.23 & 154 & 32.04 & 45.45 & 63.64 & 66.67 & 1.51 & 1.11 & $1.19^{*}$ & 13.27 \\
\hline $\operatorname{Pr} 11-6-4-1-2$ & 104.67 & 140.92 & 29.01 & $56.56^{*}$ & $72.73^{*}$ & $78.57^{*}$ & $2.01^{*}$ & 1.14 & 1.05 & 11.27 \\
\hline Pr14-2-3-2 & 102.02 & 146.66 & 33.39 & 16.6 & 54.55 & 56.62 & 1.18 & 1.11 & 1.19 & 11.96 \\
\hline RP-2 & 100.02 & 128.39 & 37.22 & 25.17 & 63.64 & 69.23 & 1.51 & 1.10 & 1.05 & $14.09^{*}$ \\
\hline IAC Alvorada & 114.32 & 161.19 & 32.14 & 49.32 & 54.55 & 58.33 & 1.20 & 1.06 & 1.11 & 13.36 \\
\hline Pérola & 103.25 & 150.12 & 36.08 & 43.49 & 63.64 & 66.67 & 1.51 & 1.09 & 1.15 & 10.44 \\
\hline IAC Diplomata & 109.17 & 141.76 & 33.15 & 38.07 & 60.61 & 64.74 & 1.40 & 1.09 & 1.11 & 11.28 \\
\hline IAC Una & 109.02 & 148.59 & 32.45 & 43.44 & 54.55 & 50.00 & 1.20 & 1.12 & 1.36 & 13.45 \\
\hline Mean & 105.25 & 145.93 & 34.38 & 47.28 & 62.35 & 64.27 & 1.50 & 1.11 & 1.19 & 12.50 \\
\hline C.V. (\%) & 3.85 & 3.61 & 4.01 & 19.98 & 7.59 & 23.02 & 6.92 & 5.71 & 0.44 & 4.44 \\
\hline${ }^{*}$ LSD & 2.85 & 4.92 & 2.23 & 7.13 & 5.20 & 5.25 & 0.05 & 0.06 & 0.04 & 0.51 \\
\hline
\end{tabular}

${ }^{*}$ Dunnett Test $(5 \%)$ in relation to the best corresponding control of the black commercial group (P) (IAC-Una or IAC-Diplomata) and of the carioca commercial group (C)

(IAC-Alvorada or Pérola). Values in bold print represent the best control for each commercial group 
Table 2. Values of water absoption capacity before cooking (Peanc) and after cooking (Peapc), cooking time (CT), percentage of whole grains after cooking (PWG), volumetric expansion before cooking (EXPVbc) and after cooking (EXPVac), dry/raw grain density (DD), grain density after soaking (SD) and grain density after cooking (CD) and total soluble solids in the broth (TSSb) of the grains of cultivars/ lines of common bean, grown in the dry season in the 2010/2011 crop years in the state of Sáo Paulo

\begin{tabular}{|c|c|c|c|c|c|c|c|c|c|c|}
\hline $\begin{array}{c}\text { Cultivars and } \\
\text { Lines }\end{array}$ & $\begin{array}{c}\text { Peanc } \\
(\%)\end{array}$ & $\begin{array}{l}\text { Peapc } \\
(\%)\end{array}$ & $\begin{array}{c}\text { CT } \\
\text { (min.) }\end{array}$ & $\begin{array}{l}\text { PWG } \\
(\%)\end{array}$ & $\begin{array}{c}\text { EXPVbc } \\
(\%)\end{array}$ & $\begin{array}{c}\text { EXPVac } \\
(\%)\end{array}$ & $\begin{array}{c}\text { DD } \\
\text { (g.mL) }\end{array}$ & SD (g.mL) & $\begin{array}{c}\text { CD } \\
(\mathrm{g} \cdot \mathrm{mL})\end{array}$ & $\begin{array}{c}\text { TSSb } \\
(\%)\end{array}$ \\
\hline$C 2-1-6-1$ & $106.92^{*}$ & $157.89^{*}$ & $24.13^{*}$ & 41.26 & 58.84 & 65.02 & 1.30 & $1.10^{*}$ & $1.13^{*}$ & 10.92 \\
\hline$C 2-1-6-1-1$ & 104.32 & 137.14 & 33.25 & 40.21 & 66.67 & 70.00 & $2.01^{*}$ & 1.06 & $1.45^{*}$ & 11.02 \\
\hline$C 2-3-1-1-2$ & $110.12^{*}$ & $159.01^{*}$ & 28.14 & 39.65 & 63.64 & 69.23 & 1.50 & $1.07^{*}$ & 1.11 & 10.21 \\
\hline C4-5-4-1-2 & $106.94^{*}$ & 141.12 & 27.32 & 33.52 & 50.00 & 61.54 & 1.20 & $1.19^{*}$ & 1.12 & 11.56 \\
\hline C4-8-1-1 & 101.14 & 142.23 & 27.25 & 47.12 & 60.00 & 69.23 & 1.49 & $1.15^{*}$ & 1.12 & 12.36 \\
\hline CHC 97-29 & 104.02 & 144.56 & 30.16 & 40.32 & 63.64 & 69.23 & 1.50 & $1.07^{*}$ & 1.11 & 10.56 \\
\hline CHP 98-59 & 107.23 & 148.78 & 29.56 & $59.32 *$ & 50.00 & 61.54 & 1.20 & $1.19^{*}$ & 1.12 & 10.21 \\
\hline CNFC 10104 & 106.14 & $151.22 *$ & 32.33 & 44.31 & 53.03 & 60.47 & 1.20 & $1.11^{*}$ & $1.21^{*}$ & 11.63 \\
\hline BRS-Cometa & 100.69 & 139.54 & 26.11 & 54.02 & 58.33 & 58.33 & 1.18 & 0.96 & 1.11 & 11.25 \\
\hline Eldorado & 100.54 & 140.63 & 25.52 & 47.88 & 50.00 & 44.44 & 1.17 & $1.13^{*}$ & $1.54^{*}$ & 10.10 \\
\hline BRS-Esplendor & 99.65 & 149.65 & 33.25 & $56.01^{*}$ & 50.00 & 50.00 & 1.20 & $1.19^{*}$ & $1.43^{*}$ & 12.14 \\
\hline BRS-Estilo & 101.01 & 137.52 & 29.18 & 52.26 & 52.78 & 50.93 & 1.18 & $1.09 *$ & $1.36^{*}$ & 11.23 \\
\hline LP-04-03 & 106.69 & 141.25 & 31.02 & 46.65 & 63.64 & 60.00 & 1.51 & 1.01 & $1.44^{*}$ & 13.01 \\
\hline LP-05-77 & 100.22 & $154.09 *$ & 28.47 & 38.25 & 60.00 & 60.00 & 1.50 & 1.02 & $1.42^{*}$ & 10.16 \\
\hline MAll-22 & 99.98 & 140.12 & 29.33 & 42.36 & 66.67 & 70.00 & $2.04^{*}$ & $1.19^{*}$ & $1.47^{*}$ & 10.26 \\
\hline IAC Imperador & 102.69 & 144.63 & 25.12 & 33.69 & 63.43 & 63.33 & 1.68 & $1.07^{*}$ & $1.44^{*}$ & 12.01 \\
\hline P5-4-4-1 & 103.01 & 142.87 & 24.36 & 50.12 & 54.55 & 61.54 & 1.21 & $1.17^{*}$ & $1.19^{*}$ & 10.21 \\
\hline Pr11-3-5-1 & 105.12 & 139.56 & 28.45 & 47.89 & 54.55 & 64.29 & 1.20 & $1.16^{*}$ & 1.08 & 10.32 \\
\hline Pr11-6-4-1-2 & 100.24 & 130.54 & 30.11 & 39.56 & 62.18 & 68.89 & 1.30 & 1.02 & 1.09 & 13.25 \\
\hline Pr14-2-3-2 & 99.96 & 149.65 & 31.12 & 40.18 & 75.00 & 80.00 & 1.98 & 1.05 & 1.04 & 11.54 \\
\hline $\mathrm{RP}-2$ & 101.56 & 125.01 & 26.54 & 49.65 & 69.23 & 71.43 & 1.51 & 0.95 & 1.15 & 10.99 \\
\hline IAC Alvorada & 103.56 & 146.29 & 32.01 & 56.17 & 66.67 & 73.33 & 1.51 & 1.03 & 1.06 & 13.21 \\
\hline Pérola & 104.21 & 142.56 & 27.14 & 56.92 & 70.30 & 74.92 & 1.67 & 1.01 & 1.08 & 11.65 \\
\hline IAC Diplomata & 105.22 & 141.12 & 28.13 & 40.37 & 63.03 & 65.02 & 1.31 & 1.03 & 1.10 & 11.1 \\
\hline IAC Una & 107.85 & 145.03 & 30.21 & 39.16 & 72.73 & 78.57 & 1.96 & 1.02 & 1.14 & 12.54 \\
\hline Mean & 103.50 & 143.40 & 29.13 & 35.89 & 61.81 & 65.25 & 1.53 & 1.07 & 1.26 & 11.34 \\
\hline C.V. (\%) & 3.02 & 4.06 & 4.33 & 15.26 & 9.13 & 33.15 & 7.14 & 5.41 & 0.32 & 3.91 \\
\hline *LSD & 2.54 & 5.23 & 3.24 & 5.13 & 4.82 & 4.21 & 0.06 & 0.04 & 0.05 & 0.62 \\
\hline
\end{tabular}

* Dunnett Test (5\%) in relation to the best corresponding control of the black commercial group (P) (IAC-Una or IAC-Diplomata) and of the carioca commercial group (C) (IAC-Alvorada or Pérola). Values in bold print represent the best control for each commercial group

to a graduated cylinder with a $100 \mathrm{~mL}$ capacity containing $50 \mathrm{~mL}$ of water, and the volume of displaced water was noted. The technological characteristics of volumetric expansion of grains before cooking (EXPVbc), volumetric expansion after cooking (EXPVac), dry grain density (DD), grain density after soaking (SD) and grain density after cooking (CD) were calculated using the formulas: $\mathrm{EXPVbc}=[(\mathrm{vs}-\mathrm{vr}) / \mathrm{vs}] \mathrm{x}$ $100 ; \mathrm{EXPVac}=[(\mathrm{vc}-\mathrm{vr}) / \mathrm{vc}] \times 100 ; \mathrm{DD}=\mathrm{dw} / \mathrm{vr} ; \mathrm{SD}=\mathrm{sw} /$ vs; $\mathrm{CD}=\mathrm{cw} / \mathrm{vc}$; in which $\mathrm{vr}=$ volume of water displaced by raw grains; vs = volume of water displaced by grains after soaking; $\mathrm{vc}=$ volume of water displaced by the grains after cooking; $\mathrm{dw}=$ weight of the dry/raw grains; $\mathrm{sw}=$ weight of the grains after soaking (5).

The quantity of total soluble solids in the cooking broth (TSSb) was determined based on the method described by Perina et al. (2010). According to the adapted method, a 10 $\mathrm{g}$ sample of common bean grains was soaked in $100 \mathrm{~mL}$ of distilled water for 16 hours. Beakers with the beans were then heated on a hot plate, using the cooking times previously established for each line/cultivar in the cooking tests. Then, the broths obtained from the cooking were filtered and collected in clean, dry beakers of known weights. The beakers with the broths were dried in a ventilated laboratory oven at $60{ }^{\circ} \mathrm{C}$ and, after complete drying of the broth, the beakers were once more weighed. The total soluble solids contents in the broth were determined by the formula $\operatorname{TSSb}(\%)=$ $[(\mathrm{BW}+\mathrm{DR})-(\mathrm{BW}) / \mathrm{MS}] \times 100$, where $\mathrm{BW}=$ beaker weight; $\mathrm{DR}=$ dry residue; $\mathrm{DW}=$ dry weight of the grains.

The results obtained were subjected to combined analyses of variance for each growing period (rainy, dry and winter seasons) and for the three seasons together (combined analysis), using the model PROC GLM of ANOVA of the SAS (Statistical Analysis System) computing program. The mean values of the genotypes of the black and carioca commercial group were compared by the Dunnett test at the 5\% significance level with the best control of the black commercial group (IAC Una and IAC Diplomata) and of the carioca commercial group (IAC Alvorada e Pérola), 
Table 3. Values of water absoption capacity before cooking (Peanc) and after cooking (Peapc), cooking time (CT), percentage of whole grains after cooking (PWG), volumetric expansion before cooking (EXPVbc) and after cooking (EXPVac), dry/raw grain density (DD), grain density after soaking (SD) and grain density after cooking (CD) and total soluble solids in the broth (TSSb) of the grains of cultivars/ lines of common bean, grown in the rainy season in the 2009/2010 crop years in the state of São Paulo

\begin{tabular}{|c|c|c|c|c|c|c|c|c|c|c|}
\hline $\begin{array}{l}\text { Cultivars and } \\
\text { Lines }\end{array}$ & $\begin{array}{l}\text { Peanc } \\
(\%)\end{array}$ & $\begin{array}{l}\text { Peapc } \\
\text { (\%) }\end{array}$ & $\begin{array}{c}\text { CT } \\
\text { (min.) }\end{array}$ & $\begin{array}{l}\text { PWG } \\
(\%)\end{array}$ & $\begin{array}{c}\text { EXPVbc } \\
(\%)\end{array}$ & $\begin{array}{c}\text { EXPVac } \\
(\%)\end{array}$ & $\begin{array}{c}\text { DD } \\
\text { (g.mL) }\end{array}$ & $\begin{array}{c}\text { SD } \\
\text { (g.mL) }\end{array}$ & $\begin{array}{c}\text { CD } \\
\text { (g.mL) }\end{array}$ & $\begin{array}{c}\text { TSSb } \\
(\%)\end{array}$ \\
\hline C2-1-6-1 & $107.14^{*}$ & $155.16^{*}$ & $21.15^{*}$ & 32.56 & $67.42^{*}$ & $73.26^{*}$ & $1.67^{*}$ & 1.11 & 1.12 & 11.02 \\
\hline$C 2-1-6-1-1$ & $108.16^{*}$ & $146.38^{*}$ & $23.22^{*}$ & 40.12 & 57.07 & 65.08 & 1.21 & 1.07 & 1.16 & 10.54 \\
\hline$C 2-3-1-1-2$ & $108.54^{*}$ & 151.69* & $24.06^{*}$ & 39.16 & 60.61 & 70.48 & $1.41^{*}$ & 1.01 & 1.14 & 10.12 \\
\hline C4-5-4-1-2 & 103.12 & 129.14 & 27.12 & 60.02 & $70.43^{*}$ & $77.46^{*}$ & $2.01^{*}$ & 1.09 & 1.12 & 11.12 \\
\hline C4-8-1-1 & 103.05 & 136.12 & $26.14^{*}$ & 39.18 & 54.55 & 66.67 & 1.21 & 1.18 & 1.12 & 10.21 \\
\hline CHC 97-29 & 101.16 & 140.15 & 29.30 & 51.00 & 57.07 & 62.45 & 1.21 & 0.93 & 1.15 & 10.01 \\
\hline CHP 98-59 & 103.23 & 139.01 & 27.49 & 31.18 & 58.33 & 66.67 & 1.20 & 1.07 & 1.07 & 10.56 \\
\hline CNFC 10104 & 102.19 & 134.10 & 24.56 & 44.85 & 54.55 & 64.29 & 1.20 & 1.18 & 1.14 & $12.01^{*}$ \\
\hline BRS-Cometa & 100.22 & $144.44^{*}$ & $25.02^{*}$ & 39.65 & 50.00 & 64.29 & 1.21 & $1.30^{*}$ & 1.16 & 11.21 \\
\hline Eldorado & 101.14 & 136.12 & 26.35 & 54.32 & 54.29 & 65.08 & 1.20 & 1.18 & 1.12 & 9.99 \\
\hline BRS-Esplendor & 99.96 & 125.02 & 31.14 & 44.59 & 60.99 & 65.02 & 1.31 & 0.98 & 1.15 & 10.00 \\
\hline BRS-Estilo & 105.01 & 133.00 & 30.02 & $81.95^{*}$ & $72.73^{*}$ & $78.57^{*}$ & $2.01^{*}$ & 1.11 & 1.16 & 11.14 \\
\hline LP-04-03 & 104.08 & $148.01^{*}$ & $22.16^{*}$ & 32.33 & 60.00 & 71.43 & $1.51^{*}$ & $1.26^{*}$ & 1.18 & 10.25 \\
\hline LP-05-77 & 101.12 & 139.14 & 29.14 & 29.18 & $63.64^{*}$ & $73.33^{*}$ & $1.51^{*}$ & 1.14 & 1.09 & 10.10 \\
\hline MAll-22 & 103.14 & $149.17^{*}$ & $25.02^{*}$ & $79.14^{*}$ & $65.45^{*}$ & $74.44^{*}$ & $1.68^{*}$ & 1.17 & 1.15 & 9.56 \\
\hline IAC Imperador & 101.99 & 133.69 & $25.41^{*}$ & 60.22 & $72.73^{*}$ & $75.00^{*}$ & $2.02^{*}$ & 1.10 & $1.20^{*}$ & 11.12 \\
\hline P5-4-4-1 & 102.43 & 140.03 & 27.56 & 69.99 & $75.00^{*}$ & $75.00^{*}$ & $2.01^{*}$ & 1.01 & $1.26^{*}$ & 10.32 \\
\hline $\operatorname{Pr} 11-3-5-1$ & 103.56 & 136.54 & 30.01 & 34.74 & $64.90^{*}$ & $73.33^{*}$ & $1.82^{*}$ & 1.05 & 1.11 & 10.65 \\
\hline Pr11-6-4-1-2 & 104.15 & 130.98 & 23.12 & 39.65 & 58.89 & 65.93 & 1.30 & 1.08 & 1.12 & 12.14 \\
\hline Pr14-2-3-2 & 101.98 & 131.25 & 26.54 & $71.14^{*}$ & $66.67^{*}$ & $76.92^{*}$ & $2.02^{*}$ & 1.08 & 1.16 & $12.45^{*}$ \\
\hline RP-2 & 103.78 & 136.74 & 31.16 & 48.95 & 60.00 & 69.23 & 1.51 & 1.00 & 1.18 & 10.12 \\
\hline IAC Alvorada & 104.15 & 131.23 & 28.02 & 68.13 & 56.55 & 66.67 & 1.20 & 1.18 & 1.10 & 10.21 \\
\hline Pérola & 102.05 & 135.01 & 29.54 & 62.02 & 54.55 & 64.29 & 1.20 & 1.16 & 1.13 & 13.01 \\
\hline IAC Diplomata & 103.17 & 138.14 & 23.11 & 60.07 & 58.33 & 64.29 & 1.21 & 1.08 & 1.18 & 10.56 \\
\hline IAC Una & 101.18 & 140.56 & 22.03 & 40.63 & 55.81 & 65.08 & 1.20 & 1.14 & 1.14 & 11.14 \\
\hline Mean & 102.54 & 135.05 & 26.34 & 50.19 & 61.22 & 69.37 & 1.48 & 1.11 & 1.14 & 10.78 \\
\hline C.V. (\%) & 3.02 & 3.16 & 2.89 & 16.18 & 9.19 & 19.15 & 5.99 & 6.13 & 0.42 & 2.96 \\
\hline${ }^{*}$ LSD & 2.92 & 6.01 & 2.16 & 7.25 & 5.23 & 5.19 & 0.04 & 0.06 & 0.07 & 0.51 \\
\hline
\end{tabular}

*Dunnett Test $(5 \%)$ in relation to the best corresponding control of the black commercial group (P) (IAC-Una or IAC-Diplomata) and of the carioca commercial group (C) (IAC-Alvorada or Pérola). Values in bold print represent the best control for each commercial group

respectively. The Pearson linear correlation coefficients were also determined with the aid of the GENES computational program (Cruz, 2006).

\section{RESULTS AND DISCUSSION}

The results analyzed showed that in the winter season (Table 1), the mean value of the percentage of water absorption by the grains $(105.25 \%)$ was greater than in the dry season $(103.50 \%)$ (Table 2 ) and in the rainy season (102.54\%) (Table 3); nevertheless, the genotypes grown in the rainy season exhibited a lower mean cooking time (26.34) (Table 3) in relation to the mean value of the genotypes grown in the winter (34.38) (Table 1). Various studies indicate an inverse association between cooking time and water absorption (Dalla Corte et al., 2003; Rodrigues et al., 2005a). Nevertheless, the genotype with the highest water absorption capacity will not necessarily have the shortest cooking time, as already reported by Carbonell et al. (2003) and Durigan et al. (1978).

Based on the results obtained for cooking time, it was seen that within the common bean genotypes assessed, the cooking times of the grains from line C2-1-6-1 were the shortest, 21 and 24 minutes, in the rainy and dry crop seasons, respectively (Tables 2 and 3). This result is important because it generates energy savings and reduces the time spent on bean preparation, given that the search for rapidly prepared foods and greater practicality is becoming ever greater. In addition, these results may also play an important role in the commercial acceptance of a cultivar and its acceptance in the production chain. Considering the results obtained in this study, it was seen that the rainy crop season not only exhibited the shortest mean cooking time (26.34), but it was also the most suitable season for differentiating superior genotypes for cooking time. The result obtained in the study developed by Farinelli and Lemos (2010) to 
Table 4. Values of water absoption capacity before cooking (Peanc) and after cooking (Peapc), cooking time (CT), percentage of whole grains after cooking (PWG), volumetric expansion before cooking (EXPVbc) and after cooking (EXPVac), dry/raw grain density (DD), grain density after soaking (SD) and grain density after cooking (CD) and total soluble solids in the broth (TSSb) of the grains of cultivars/ lines of common bean, grown in the 2009/2010/2011 crop years in the state of São Paulo

\begin{tabular}{|c|c|c|c|c|c|c|c|c|c|c|}
\hline $\begin{array}{l}\text { Cultivars and } \\
\text { Lines }\end{array}$ & $\begin{array}{l}\text { Peanc } \\
(\%)\end{array}$ & $\begin{array}{l}\text { Peapc } \\
(\%)\end{array}$ & $\begin{array}{c}\text { CT } \\
(\min .)\end{array}$ & $\begin{array}{l}\text { PWG } \\
(\%)\end{array}$ & $\begin{array}{c}\text { EXPVbc } \\
(\%)\end{array}$ & $\begin{array}{c}\text { EXPVac } \\
(\%)\end{array}$ & $\begin{array}{c}\text { DD } \\
\text { (g.mL) }\end{array}$ & $\begin{array}{c}\text { SD } \\
\text { (g.mL) }\end{array}$ & $\begin{array}{c}\mathrm{CD} \\
\text { (g.mL) }\end{array}$ & $\begin{array}{c}\text { TSSb } \\
(\%)\end{array}$ \\
\hline C2-1-6-1 & 109.27 & $153.46^{*}$ & $26.22^{*}$ & 30.14 & 61.62 & 68.07 & 1.42 & 1.12 & 1.11 & 11.38 \\
\hline$C 2-1-6-1-1$ & 106.91 & 146.22 & 29.21 & 53.56 & 65.49 & 70.67 & $1.73^{*}$ & 1.09 & $1.23^{*}$ & 11.79 \\
\hline$C 2-3-1-1-2$ & 109.05 & $152.46^{*}$ & 29.32 & 35.76 & 63.64 & 69.65 & 1.46 & 1.03 & 1.11 & 11.12 \\
\hline C4-5-4-1-2 & 104.92 & 139.57 & 32.00 & 50.36 & 62.37 & 68.56 & $1.56^{*}$ & 1.10 & 1.13 & 11.84 \\
\hline C4-8-1-1 & 104.21 & 141.67 & $29.06^{*}$ & 51.42 & 61.08 & 68.95 & 1.44 & 1.13 & 1.12 & 11.25 \\
\hline CHC 97-29 & 102.16 & 146.63 & 30.57 & 43.43 & 64.98 & 69.90 & $1.57^{*}$ & 1.02 & 1.11 & 11.16 \\
\hline CHP 98-59 & 103.79 & 145.16 & 30.46 & 36.36 & 58.33 & 62.74 & 1.30 & 1.10 & 1.18 & 10.94 \\
\hline CNFC 10104 & 102.36 & 142.34 & 29.47 & 47.37 & 54.04 & 58.25 & 1.20 & $1.17^{*}$ & 1.27 & 11.81 \\
\hline BRS-Cometa & 100.90 & 143.87 & 29.27 & 53.14 & 56.11 & 60.87 & 1.30 & $1.17^{*}$ & 1.21 & 11.35 \\
\hline Eldorado & 101.91 & 136.98 & 30.05 & 46.01 & 54.90 & 55.40 & 1.26 & $1.16^{*}$ & $1.35^{*}$ & 10.49 \\
\hline BRS-Esplendor & 97.82 & 141.00 & 33.48 & 58.95 & 64.27 & 66.55 & $1.82^{*}$ & 1.08 & $1.23^{*}$ & 11.81 \\
\hline BRS-Estilo & 103.98 & 140.21 & 32.33 & 60.85 & 59.51 & 61.78 & 1.46 & 1.12 & $1.26^{*}$ & 11.88 \\
\hline LP-04-03 & 106.39 & 146.29 & $28.15^{*}$ & 40.97 & 59.40 & 60.48 & 1.41 & 1.13 & $1.36^{*}$ & 12.41 \\
\hline LP-05-77 & 102.11 & 147.00 & 31.27 & 39.66 & 60.66 & 65.87 & 1.41 & 1.07 & 1.18 & 11.38 \\
\hline MAll-22 & 104.95 & 141.63 & 31.12 & 57.69 & 62.22 & 68.66 & $1.64^{*}$ & 1.16 & $1.25^{*}$ & 10.47 \\
\hline IAC Imperador & 102.55 & 136.89 & $28.18^{*}$ & 52.75 & 63.99 & 65.65 & $1.63^{*}$ & 1.09 & $1.28^{*}$ & 11.56 \\
\hline P5-4-4-1 & 103.59 & 141.71 & $27.12^{*}$ & 61.66 & 64.40 & 67.74 & $1.58^{*}$ & 1.10 & $1.22 *$ & 11.18 \\
\hline Pr11-3-5-1 & 104.64 & 143.37 & 30.17 & 42.69 & 61.03 & 68.10 & 1.51 & 1.11 & 1.13 & 11.41 \\
\hline Pr1 1-6-4-1-2 & 103.02 & 134.15 & $27.41^{*}$ & 45.26 & 64.60 & 71.13 & $1.54^{*}$ & 1.08 & 1.09 & 12.22 \\
\hline $\operatorname{Pr} 14-2-3-2$ & 101.32 & 142.52 & 30.35 & 42.64 & 65.41 & $71.18^{*}$ & $1.73^{*}$ & 1.08 & 1.13 & 11.98 \\
\hline RP-2 & 101.79 & 130.05 & 32.04 & 41.26 & 64.29 & 69.96 & 1.51 & 1.02 & 1.13 & 11.73 \\
\hline IAC Alvorada & 107.34 & 146.24 & 31.12 & 57.87 & 59.26 & 66.11 & 1.30 & 1.09 & 1.09 & 12.26 \\
\hline Pérola & 103.17 & 142.56 & 31.32 & 54.14 & 62.83 & 68.63 & 1.46 & 1.09 & 1.12 & 11.70 \\
\hline IAC Diplomata & 105.85 & 140.34 & 28.13 & 46.17 & 60.66 & 64.68 & 1.31 & 1.07 & 1.13 & 10.98 \\
\hline IAC Una & 106.02 & 144.73 & 28.23 & 41.08 & 61.03 & 64.55 & 1.45 & 1.09 & 1.21 & 12.38 \\
\hline Mean & 104.00 & 142.68 & 30.21 & 47.65 & 61.44 & 66.17 & 1.48 & 1.10 & 1.19 & 11.54 \\
\hline C.V. (\%) & 4.62 & 5.02 & 5.48 & 23.15 & 11.23 & 8.59 & 23.15 & 6.77 & 5.93 & 3.59 \\
\hline${ }^{*}$ LSD & 3.70 & 4.98 & 2.32 & 6.48 & 5.44 & 4.60 & 0.07 & 0.06 & 0.08 & 0.48 \\
\hline
\end{tabular}

*Dunnett Test $(5 \%)$ in relation to the best corresponding control of the black commercial group (P) (IAC-Una or IAC-Diplomata) and of the carioca commercial group (C) (IAC-Alvorada or Pérola). Values in bold print represent the best control for each commercial group

assess the behavior of common bean genotypes in regard to the cooking time of beans produced in different seasons showed that the common bean grains produced in the 2005 rainy crop season had a greater mean cooking time than those produced in the 2005 and 2006 dry crop seasons. This fact may be explained by the possibility of interference of environmental conditions in the physiological quality and in change in the integrity of the seed coat, with consequent changes in regard to water absorption capacity and cooking time (Carbonell et al., 2003; Dalla Corte et al., 2003; Kigel, 1999; Lemos et al., 2004).

The percentage of whole grains after cooking is another relevant characteristic to consider in the common bean industrialization process because genotypes are sought that exhibit low cooking time and a high percentage of whole grains. In this characteristic, variability was observed between the genotypes and the observed environmental effect (Dalla Corte et al., 2003). The consumer has a tendency to prefer beans with good consistency of the broth while maintaining the integrity of the cooked grains (Bassinello et al., 2003). According to the mean results obtained (Tables 1, 2 and 3 ), the presence of whole grains varied, from $35.89 \%$ to $50.19 \%$ to $47.28 \%$. It was also observed that the genotypes with the lowest percentage of water absorption after cooking exhibited the greatest percentage of whole grains.

The mean total soluble solids content in the broth in beans from the rainy crop season was $10.78 \%$, probably because the cooking time was less and the percentage of whole grains was high, not allowing the release of soluble solids to the broth. For the winter crop season, where the soluble solids content was greater $(12.50 \%)$, there was an increase in cooking time, which may have favored the increase in the TSSb content. For beans from the dry crop season, cooking time was greater than for beans from the rainy crop season and the total soluble solids content in the broth was $11.34 \%$. In general, the total soluble solids content in the broth was influenced by the cooking time and by the percentage of whole grains. 
Table 5. Estimates of the Pearson correlation coefficient between the technological characteristics assessed in grains of cultivars and lines of common bean from trials carried out in the rainy season, dry season and winter season in combined analysis

\begin{tabular}{|c|c|c|c|c|c|c|c|c|c|}
\hline & \multicolumn{9}{|c|}{ Pearson Correlation Coefficient - "Rainy" } \\
\hline & Peapc & PWG & CT & EXPVbc & EXPVac & DD & SD & CD & TSSb \\
\hline Peanc & $0.34^{* *}$ & $-0.18^{* *}$ & -0.08 & -0.01 & 0.05 & $-0.22^{* *}$ & $0.32^{* *}$ & 0.07 & 0.03 \\
\hline Peapc & & $-0.65^{*}$ & $-0.24^{* *}$ & 0.13 & $0.54^{*}$ & -0.08 & -0.08 & $0.48^{* *}$ & -0.13 \\
\hline PWG & & & $0.39^{* *}$ & 0.01 & $-0.21^{* *}$ & -0.13 & -0.09 & $-0.20^{* *}$ & $0.19^{* *}$ \\
\hline CT & & & & -0.12 & -0.16 & -0.06 & $0.24^{* *}$ & -0.03 & $0.57^{*}$ \\
\hline EXPVbc & & & & & $0.73^{*}$ & $0.84^{*}$ & $-0.62^{*}$ & 0.16 & 0.05 \\
\hline EXPVac & & & & & & $0.70^{*}$ & $-0.43^{* *}$ & $-0.25^{* *}$ & $0.20^{* *}$ \\
\hline DD & & & & & & & $-0.46^{* *}$ & -0.13 & 0.03 \\
\hline SD & & & & & & & & $0.27^{* *}$ & $0.28^{* *}$ \\
\hline CD & & & & & & & & & 0.10 \\
\hline
\end{tabular}

\begin{tabular}{|c|c|c|c|c|c|c|c|c|c|}
\hline & \multicolumn{9}{|c|}{ Pearson Correlation Coefficient - "Dry" } \\
\hline & Peapc & PWG & CT & EXPVbc & EXPVac & DD & SD & CD & TSSb \\
\hline Peanc & $0.43^{* *}$ & $-0.22^{* *}$ & -0.09 & -0.02 & 0.07 & $-0.27^{* *}$ & $0.34^{* *}$ & 0.06 & 0.04 \\
\hline Peapc & & $-0.66^{*}$ & $-0.19 * *$ & 0.09 & $0.57^{*}$ & -0.04 & -0.04 & $0.41^{* *}$ & -0.10 \\
\hline PWG & & & $-0.42 * *$ & 0.03 & $-0.26 * *$ & -0.15 & -0.08 & $-0.22^{* *}$ & $0.18^{* *}$ \\
\hline CT & & & & -0.11 & -0.15 & -0.07 & $0.28^{* *}$ & -0.02 & $0.55^{*}$ \\
\hline EXPVbc & & & & & $0.76^{*}$ & $0.91^{*}$ & $-0.61^{*}$ & 0.14 & 0.04 \\
\hline EXPVac & & & & & & $0.73^{*}$ & $-0.46^{* *}$ & $-0.20^{* *}$ & $0.29 * *$ \\
\hline DD & & & & & & & $-0.41 * *$ & -0.14 & 0.05 \\
\hline SD & & & & & & & & $0.26^{* *}$ & $0.26^{* *}$ \\
\hline \multirow[t]{3}{*}{ CD } & & & & & & & & & 0.12 \\
\hline & \multicolumn{9}{|c|}{ Pearson Correlation Coefficient - "Winter" } \\
\hline & Peapc & PWG & CT & EXPVbc & EXPVac & DD & SD & CD & TSSb \\
\hline Peanc & $0.30^{* *}$ & $-0.24^{* *}$ & -0.06 & -0.03 & 0.05 & $-0.21 * *$ & $0.39 * *$ & 0.10 & -0.05 \\
\hline Peapc & & $-0.65^{*}$ & $-0.32^{* *}$ & 0.10 & $0.55^{*}$ & -0.06 & -0.05 & $0.44^{* *}$ & -0.15 \\
\hline PWG & & & $0.43^{* *}$ & 0.02 & $-0.29 * *$ & -0.14 & -0.07 & $-0.25^{* *}$ & $0.20^{* *}$ \\
\hline CT & & & & -0.14 & -0.17 & -0.09 & $0.25^{* *}$ & -0.04 & $0.52^{*}$ \\
\hline EXPVbc & & & & & $0.81^{*}$ & $0.88^{*}$ & $-0.69^{*}$ & $0.18^{* *}$ & 0.05 \\
\hline XPVpc & & & & & & $0.69^{*}$ & $-0.42^{* *}$ & $-0.25^{* *}$ & $0.32 * *$ \\
\hline DD & & & & & & & $-0.46^{* *}$ & -0.13 & 0.03 \\
\hline SD & & & & & & & & $0.24^{* *}$ & $0.21^{* *}$ \\
\hline \multirow[t]{3}{*}{ CD } & & & & & & & & & 0.09 \\
\hline & \multicolumn{9}{|c|}{ Pearson Correlation Coefficient - "Combined Analysis" } \\
\hline & Peapc & PWG & CT & EXPVbc & EXPVac & DD & SD & CD & TSSb \\
\hline Peanc & $0.35^{* *}$ & $0.26^{* *}$ & -0.04 & -0.02 & 0.05 & $-0.25^{* *}$ & $0.36^{* *}$ & 0.08 & -0.02 \\
\hline Peapc & & $-0.61^{*}$ & $-0.25^{* *}$ & 0.12 & $0.51^{*}$ & -0.06 & -0.05 & $0.46^{* *}$ & -0.11 \\
\hline PWG & & & $0.40^{* *}$ & 0.01 & $-0.23^{* *}$ & -0.11 & -0.07 & $-0.20^{* *}$ & $0.21^{* *}$ \\
\hline CT & & & & -0.14 & $-0.18^{* *}$ & -0.06 & $0.27^{* *}$ & -0.02 & $0.57^{*}$ \\
\hline EXPVbc & & & & & $0.78^{*}$ & $0.90^{*}$ & $-0.66^{*}$ & 0.15 & 0.01 \\
\hline EXPVac & & & & & & $0.71^{*}$ & $-0.44^{* *}$ & $-0.21^{* *}$ & $0.30^{* *}$ \\
\hline DD & & & & & & & $-0.43^{* *}$ & -0.10 & 0.01 \\
\hline SD & & & & & & & & $0.25^{* *}$ & $0.24^{* *}$ \\
\hline CD & & & & & & & & & 0.11 \\
\hline
\end{tabular}

**,*: Significant at $1 \%$ and at $5 \%$ level by the $t$ test. Peanc: Percentage of imbibition before cooking; Peapc: Percentage of imbibition after cooking; PWG: Percentage of whole grains; CT: Cooking time in minutes; EXPVbc: Volumetric expansion before cooking in g. $\mathrm{mL}^{-1}$; EXPVac: Volumetric expansion after cooking in g.mL $\mathrm{mL}^{-1}$; DD: Dry grain density in g.mL $\mathrm{mL}^{-1}$; SD: Grain density after soaking g.mL $\mathrm{mL}^{-1}$; CD: Grain density after cooking g.mL ${ }^{-1}$; TSSb: Percentage of total soluble solids in the broth after cooking.

According to combined analysis (Table 4), the mean values of Peanc showed variation from $97 \%$ to $109 \%$, and the overall mean of water absorption before cooking was $104 \%$. This value indicates that the grains, the lines and cultivars absorbed, on average, an amount of water equivalent to their weight. The characteristics of the genotypes with this differential behavior in water absorption may be associated with the rigidity of the seed coat, cotyledon adherence, elasticity, porosity and colloidal properties in water absorption by the grains (Esteves et al., 2002). Bean grains with high values of Peanc are recommended for industrial dining halls and kitchens because they yield more after cooking.

In regard to PWG, the mean value obtained indicates that more than $50 \%$ of the grains broke open during cooking (Table 4), a result that hurts the cooking quality of the grains 
since consumers and processing industries prefer grains that do not break up after cooking.

Among the genotypes assessed, cooking time ranged from 26 to 34 minutes for the combination of the three growing seasons (Table 4). Considering the scale of Proctor and Watts (1987), in identifying the level of resistance of the grains to cooking, it was observed that the values obtained in the combination of the three growing seasons in relation to cooking time fit within the definition of normal resistance (21 to 29 minutes) to beans resistant to cooking (33 to 36 minutes). This variation is due to the genetic differences present in the genotypes, environmental influence and genotype by environment interaction (Carbonell et al., 2003; Dalla Corte et al., 2003). The genotypes C2-1-6-1, C4-81-1, LP04-03, IAC-Imperador, P5-4-4-1 and Pr11-6-4-1-2 stood out, with cooking times less than that of the control IAC-Alvorada (30.21 minutes) (Table 4). It is expected that these genotypes will be accepted for consumption since genotypes with cooking times less than 30 minutes lead to energy savings and speed in grain preparation.

In relation to the volumetric expansion rate after cooking (EXPVac), it was found that only the genotype from the black group Pr14-2-3-2 stood out from the other lines and cultivars assessed, with a volume increase of $71 \%$ (Table 4). For Resende and Corrêa (2007), the volumetric expansion rate expresses water diffusion within the grains and, according to Carbonell et al. (2003), volumetric expansion is a desirable characteristic which has an influence on acceptability of a new cultivar, which should have high grain expansion after cooking. Considering that water diffusion in the grain may be negatively affected by the degree of lignification of the grain (Teixeira et al., 2005), the results of this characteristic may be an indication of lower lignin content in the grains of genotype Pr14-2-3-2.

For the variables $\mathrm{DD}, \mathrm{SD}$ and $\mathrm{CD}$, the genotypes of the black commercial group that stood out were BRS-Esplendor, Pr14-2-3-2 and CNFC10104, respectively. Grain density after soaking $\left(1.10 \mathrm{~g} \cdot \mathrm{mL}^{-1}\right)$ and grain density after cooking (1.19 g. $\left.\mathrm{mL}^{-1}\right)$ was less when compared to dry grain density (1.48 g.mL $\mathrm{mL}^{-1}$ ) (Table 4). The lower density of the soaked and cooked grains is due to the increase in volume in relation to the weight when water is absorbed by the grain.

In estimates of the correlation coefficients among the variables analyzed, differences were seen in magnitude and in significance in the three growing seasons and for the combination of the growing seasons (Table 5). The high correlation observed among some of the traits assessed (Table 5) is important because it shows how selection for one trait affects expression of another. Nevertheless, although various significant correlations were observed among the traits assessed (Table 5), due to the low and medium magnitude of these correlations, genotypes may not be selected based on them, as desired for purposes of saving time.

\section{CONCLUSION}

The technological quality of common bean grains is variable as a function of different growing seasons. The technological characteristics are affected by the genotype, environment and genotype by environment interaction.

The genotypes C2-1-6-1, C4-8-1-1, LP04-03, IACImperador, P5-4-4-1 and Pr11-6-4-1-2 exhibited cooking time less than that of the control IAC Alvorada in the mean value of the three growing seasons.

The phenotypic correlations which exist between the characteristics of technological quality are not very expressive in selection of genotypes in breeding programs due to variation of magnitude in the different growing seasons.

\section{ACKNOWLEDGMENTS}

To CAPES for granting a scholarship and to FAPESP for support of the research project (FAPESP process 2010/096692).

\section{REFERENCES}

BASSINELLO, P.Z.; COBUCCI, R.M.A.; ULHÔA, V.G.; MELO, L.C.; DEL PELOSO, M.J. Aceitabilidade de três cultivares de feijoeiro comum. Santo Antônio de Goiás: Embrapa Arroz e Feijão, 2003. p.6. (Comunicado Técnico, n.66)

BORDIN, L.C.; COELHO, C.M.M.; SOUZA, C.A.; ZILIO, M. Diversidade genética para a padronizaçáo do tempo e percentual de hidratação preliminar ao teste de cocção de grãos de feijão. Ciência e Tecnologia de Alimentos, v.30, p.890-896, 2010. http://dx.doi. org/10.1590/S0101-20612010000400009

BRASIL. Ministério da Agricultura, Pecuária e Abastecimento. Anexo IV. Requisitos mínimos para determinaçáo do valor de cultivo e uso de feijão (Phaseolus vulgaris L.) para a inscrição no registro nacional de cultivares - RCN. Brasília: Ministério da Agricultura, Pecuária e Abastecimento, 2001.

CARBONELL, S.A.M.; CARVALHO, C.R.L.; PEREIRA, V.R. Qualidade tecnológica de grãos de genótipos de feijoeiro cultivados em diferentes ambientes. Bragantia, v.62, p.369-379, 2003. http:// dx.doi.org/10.1590/S0006-87052003000300004

CRUZ, C.D. Programa Genes: Biometria. Viçosa: UFV, 2006. p.94-107.

DALLA CORTE, A.; MODA-CIRINO, V.; SCHOLZ, M.B.S.; DESTRO, D. Environment effect on grain quality in early common bean cultivars and lines. Crop Breeding and Applied Biotechnology, v.3, p.193-202, 2003. http://dx.doi.org/10.12702/1984-7033.v03n03a03

DURIGAN, J.F.; FALEIROS, R.R.S.; LAM-SANCHEZ, A. Determinação das características tecnológicas e nutricionais de diversas variedades de feijáo (Phaseolus vulgaris L.) - I: características tecnológicas. Científica, v.6, p.215-224, 1978. 
ESTEVES, A.M.; ABREU, C.M.P.; SANTOS, C.D.; CORREA, A.D. Comparação química e enzimática de seis linhagens de feijão (Phaseolus vulgaris L.). Ciência e Agrotecnologia, v.26, p.999-1005, 2002.

FARINELLI, R., LEMOS, L.B. Qualidade nutricional e tecnológica de genótipos de feijão cultivados em diferentes safras agrícolas. Bragantia, v.69, p.759-764, 2010. http://dx.doi.org/10.1590/S000687052010000300030

GARCIA-VELA, L.A.; STANLEY, D.W. Water-holding capacity in hard-cook bean (P. vulgaris): effect of $\mathrm{pH}$ and ionic strength. Journal of Food Science, v.54, p.1080-1081, 1989. http://dx.doi. org/10.1111/j.1365-2621.1989.tb07950.x

KIGEL, J. Culinary and nutritional quality of Phaseolus vulgaris seeds as affected by environmental factors. Biotechnologie, Agronomie, Society et Enviroment, v.3, p.205-209, 1999.

LEMOS, L.B.; OLIVEIRA, R.S.; PALOMINO, E.C.; SILAVA, T.R.B. Características agronômicas e tecnológicas de genótipos de feijão do grupo comercial Carioca. Pesquisa Agropecuária Brasileira, v.39, p.319326, 2004. http://dx.doi.org/10.1590/S0100-204X2004000400004

MESQUITA, F.R.; CORREAA, A.D.; ABREU, C.M.P.; LIMA, R.A.Z.; ABREU, A.F.B. Linhagens de feijāo (Phaseolus vulgaris L.): composição química e digestibilidade protéica. Ciência e Agrotecnologia, v.31, p.1114-1121, 2007. http://dx.doi.org/10.1590/ S1413-70542007000400026

PERINA, E.F.; CARVALHO, C.R.L.; CHIORATO, A.F.; GONÇALVES, J.G.R.; CARBONELL, S.A.M. Avaliação da estabilidade e adaptabilidade de genótipos de feijoeiro (Phaseolus vulgaris L.) baseada na análise multivariada da "performance" genotípica. Ciência e Agrotecnologia, v.34, p.398-406, 2010. http://dx.doi.org/10.1590/ S1413-70542010000200018

PLHAK, L.C.; CALDWELL, K.B.; STANLEY, D.W. Comparison of methods used to characterize water imbibition in hard-to-cook beans. Journal of Food Science, v.54, p.326-336, 1989. http://dx.doi. org/10.1111/j.1365-2621.1989.tb03073.x

PROCTOR, J.R.; WATTS, B.M. Development of a modified Mattson bean cooker procedure based on sensory panel cookability evaluation. Canadian Institute of food Science and Technology, v.20, p.9-14, 1987.

RESENDE, O.; CORRÊA, P.C. Modelagem matemática do processo de hidratação de sementes de feijão. Acta Scentiarum Agronomy, v.29, p.373-378, 2007.

RIBEIRO, N.D.; RODRIGUES, J.A.; CARGNELUTTI FILHO, A.; POERSCH, N.L.; TRENTIN, M.; ROSA, S.S. Efeito de períodos de semeadura e das condiçóes de armazenamento sobre de grãos de feijāo para cozimento. Bragantia, v.66, p.157-163, 2007. http:// dx.doi.org/10.1590/S0006-87052007000100019

RODRIGUES, A.J.; RIBEIRO, D.N.; POERCHI, L.N.; LONDERO, G.M.P.; CARGNELUTTI FILHO, A. Standardization of imbibition time of common bean grains to evaluate cooking quality. Crop Breeding and Applied Biotechnology, v.4, p.465-471, 2004.

RODRIGUES, J.A.; RIBEIRO, N.D.; LONDERO, P.M.G.; FILHO, A.C. Correlação entre absorção de água e tempo de cozimento de cultivares de feijão. Ciência Rural, v.35, p.209-213, 2005a. http:// dx.doi.org/10.1590/S0103-84782005000100034

RODRIGUES, J.A.; RIBEIRO, N.D.; FILHO, A.C.; TRENTIN, M.; LONDERO, P.M.G. Qualidade para o cozimento de grãos de feijão obtidos em diferentes épocas de semeadura. Bragantia, v.64, p.369376, 2005b. http://dx.doi.org/10.1590/S0006-87052005000300006

TEIXEIRA, I.R.; BORÉM, A.; ARAÚJO, G.A.A.; ANDRADE; M.J.B. Teores de nutrientes e qualidade fisiológica de sementes de feijão em resposta à adubação foliar com zinco e manganês. Bragantia, v.64, p.83-88, 2005. http://dx.doi.org/10.1590/S0006-87052005000100009 